\title{
Changes in Vegetation of Flooded Savannas Subject to Cattle Grazing and Fire in Plains of Colombia
}

\author{
Alejandro Huertas Herrera ${ }^{1, *(\mathbb{C})}$, Brigitte L. G. Baptiste Ballera ${ }^{2,3}$, Mónica D. R. Toro-Manríquez ${ }^{1}(\mathbb{D}$, \\ María V. Lencinas ${ }^{1}$ (D), Guillermo J. Martínez Pastur ${ }^{1}$ (D) and Hugoberto Huertas Ramírez ${ }^{4}$ \\ 1 Laboratorio de Recursos Agroforestales, Centro Austral de Investigaciones Científicas (CADIC), \\ Consejo Nacional de Investigaciones Científicas y Técnicas (CONICET), Houssay 200, \\ 9410 Ushuaia, Tierra del Fuego, Argentina; monicatm@cadic-conicet.gob.ar (M.D.R.T.-M.); \\ mvlencinas@conicet.gov.ar (M.V.L.); gpastur@conicet.gov.ar (G.J.M.P.) \\ 2 Rectoría, Universidad EAN, Carrera 11 \# 78-47, 110221 Bogotá, Cundinamarca, Colombia; \\ rectoria@ean.edu.co \\ 3 Instituto de Investigación de Recursos Biológicos Alexander von Humboldt, Calle 28A \# 15-09, \\ 111311 Bogotá, Cundinamarca, Colombia \\ 4 Fundación Horizonte Verde, Calle 10 \# 20-64, 501021 Cumaral, Meta, Colombia; hugobertohuertas@gmail.com \\ * Correspondence: ahuertasherrera@cadic-conicet.gob.ar; Tel.: +54-2901-422310
}

Citation: Herrera, A.H.; Ballera, B.L.G.B.; Toro-Manríquez, M.D.R.; Lencinas, M.V.; Martínez Pastur, G.J.; Ramírez, H.H. Changes in Vegetation of Flooded Savannas Subject to Cattle Grazing and Fire in Plains of Colombia. Land 2021, 10, 108 https://doi.org/10.3390/land10020108

Received: 11 December 2020

Accepted: 20 January 2021

Published: 23 January 2021

Publisher's Note: MDPI stays neutral with regard to jurisdictional claims in published maps and institutional affiliations.

Copyright: (c) 2021 by the authors Licensee MDPI, Basel, Switzerland. This article is an open access article distributed under the terms and conditions of the Creative Commons Attribution (CC BY) license (https:// creativecommons.org/licenses/by/ $4.0 /)$

\begin{abstract}
Cattle grazing and fire are common types of management on natural ecosystems, generating several threats to the conservation of native vegetation (e.g., changes in species richness, cover, and abundance, mainly of bovine-palatable species). In this work, we analysed the response of the structure and composition of vegetation managed with different cattle stocking rates and fire in the savanna ecosystems of Colombia. The study was located in the eastern area of the Llanos region, where savannas were subjected to grazing and burning. Regarding grazing, we classified the area according to the cattle stocking rate (Bos indicus $\sim 300 \mathrm{~kg}$ ): NG = non-grazed, LS = low stocking rate $\left(0.5\right.$ ind ha $\left.{ }^{-1} \mathrm{yr}^{-1}\right)$, and $\mathrm{HS}=$ high stocking rate $\left(1.0\right.$ ind $\left.\mathrm{ha}^{-1} \mathrm{yr}^{-1}\right)$. Controlled artificial burning was applied in all the area at the beginning of the study, and surveys were conducted in the same plots at pre-burn ( $t 0)$ and four post-burn times $(t 1, t 2, t 3, t 4)$, at $15,45,75$ and 105 days after burning. Vegetation composition (species list, life-form, palatability) and structure (bare soil and vascular plant ground covers, species height and richness) were recorded at each sampling. Data were compared through ANOVAs and multivariate analyses. We found 53 species in total: 26 in the pre-burn treatment and 44 in the post-burn treatments, detecting an increase of 18 species considering all treatments. Seven natives and two exotic species represented the dominant cover ( $>50 \%)$. LS and HS had the highest number of palatable species in $t 0$ (seven species) compared with NG (two species), but this became similar after burning (14 species in NG, 12 in LS, and 11 in HS). ANOVAs and multivariate analyses showed that plant assemblages were significantly different according to the grazing treatment, and more homogeneous in pre-burn than in post-burn periods. Cattle grazing favored higher covers of dominant palatable species (e.g., Axonopus purpusii) compared with NG, but many native species with high palatability only recovered within the system after burning. In the context of the current management proposals, the search for new alternatives other than intensive cattle grazing and burning is needed to reconcile human production activities, international commitments against climate change and biodiversity conservation in the savanna landscapes.
\end{abstract}

Keywords: grasslands; land management; plant assemblages; conservation; trade-offs; Llanos region

\section{Introduction}

Fire management is a frequent practice applied in many tropical savannas to promote the vigorous regrowth of natural vegetation for cattle grazing [1,2]. Many studies support that these vegetation communities need frequent disturbances to sustain the coexistence of trees and grasslands, such as savanna burning [3,4]. Many plant species in fire-prone 
vegetation have adaptive strategies to persist under recurrent burning events and grazing $[5,6]$. In the savannas of northern South America, such as those in the Orinoco plain biogeographic region belonging to Colombia and Venezuela, burning activities have been a traditional practice that maintains the native grassland landscapes $[7,8]$, where cattle ranching represents one of the few land-uses in which savanna conservation goals can be achieved [9]. However, the use of fire is restricted in areas where it was considered harmful to nature $[4,5,7]$. The expansion of agriculture, intensive cattle production and forestry during recent decades has modified fire management practices and promoted the introduction of commercial grasslands and forest plantations $[8,10]$.

Several developing countries (e.g., Colombia) have promoted the reduction of greenhouse gases that influence climate change, generating trade-offs between burning management and intensive cattle production $[10,11]$ due to global demand for food (e.g., meat) [5]. However, satisfying the high demand for food and other ecosystem services has costs for biodiversity [12]. First, it is imperative to understand how vegetation responds to the intensification of human activities (e.g., higher cattle stocking rates in natural grasslands), and then to generate better management and conservation practices to reconcile sustainable land-use and maintain the local biodiversity of grasslands $[13,14]$. In many grassland ecosystems associated with fire and grazing dynamics, bovine-palatable species could be favored if intensive management practices are implemented [15], e.g., the selection of species by palatability and nutrient content for grazing herbivores [16]. In this context, natural grasslands with a higher cover of palatable species represent a management opportunity to integrate local conservation and production systems (e.g., free cattle grazing systems) $[17,18]$, reducing the need for monocultures of artificial grasslands with exotic species that imply an economic cost in establishing the new methods and in mechanization of the land, and improving the ecosystem services that they provide [9]. There is much international scientific interest in understanding the integration between cattle systems and conservation of natural grassland $[9,19]$, due to the fact that savanna vegetation used for cattle grazing is common in different continents (Africa, Australia and South America) [20], and cattle (e.g., Bos indicus) are one of the most widespread species of large ruminant livestock in the world [21,22]. The objective was to analyze the short-term response of vascular plant species composition (species list, life-form, palatability) and structure (height, richness and ground cover) of natural grasslands managed with different cattle stocking rates and fire in the flooded savannas of Colombia. We want to answer: (1) How does the vegetation composition vary before and after burning in non-grazed areas and when managed with different cattle stocking rates $\left(0.5\right.$ ind ha ${ }^{-1} \mathrm{yr}^{-1}$ and 1.0 ind ha $^{-1} \mathrm{yr}^{-1}$ bovine equivalent)?; (2) What is the effect of different cattle stocking rates on vegetation structure before and after burning?; and (3) How do the shared and exclusive species (total number of species or palatable species) vary according to different cattle stocking rates before and after the burning? Based on this information, we want to understand the ecological role of cattle grazing and burning practices in the local conservation and production systems in the savanna's native grasslands.

\section{Methods}

\subsection{Study Site}

The study was conducted in Bocas del Pauto locality $\left(05^{\circ} 20^{\prime}\right.$ to $05^{\circ} 10^{\prime} \mathrm{N}, 71^{\circ} 4^{\prime}$ to $70^{\circ} 48^{\prime} \mathrm{W}$, Figure 1) in the Casanare Department, in the eastern area of the Colombian Llanos. It is located on the northern shore of the Meta river and has an area of $\sim 300 \mathrm{~km}^{2}$. The vegetation corresponds to flooded savannas (henceforth savanna) characterized by natural grasslands, shrublands, and remnant of gallery forests [9]. The mean elevation is 180 m.a.s.l., with an annual average temperature of $27^{\circ} \mathrm{C}$. The hot tropical climate displays a unimodal seasonal pattern of rainfall, with a rainy season (April to October) and a dry season (November to March) [23], reaching $2200 \mathrm{~mm}_{\text {year }}^{-1}$ [24]. The period from January to March is prone to spontaneous or induced fires due to intense drought [8]. The topography is flat-concave, and parts of the savannas ( $\sim 60 \%$ of the study area) can 
be flooded for seven months each year (May to November). High elevation areas are not flooded and are the most suitable for cattle grazing during the rainy season, whereas flooded areas (low plains) and estuaries are more suitable for grazing during the dry season and transition periods [25]. The most common soil type is classified as Plinthic Acrisols [26]. Local economic activities (e.g., subsistence farmers and ranchers) are based on cattle production, agriculture and subsistence fishing. The extension of ranches ranges from 50 hectares to 8000 hectares, but most of the ranches have less than 2000 hectares. Cattle ranching occurs mostly on natural grasslands, with a mean carrying capacity of 0.5 animal ha ${ }^{-1}(\sim 300 \mathrm{~kg}$ of live weight) in the extractive-conservationist modality. The study site was selected because it has a known history of cattle grazing (traditional grazing management) and burning during the last ten years (Figure 2).

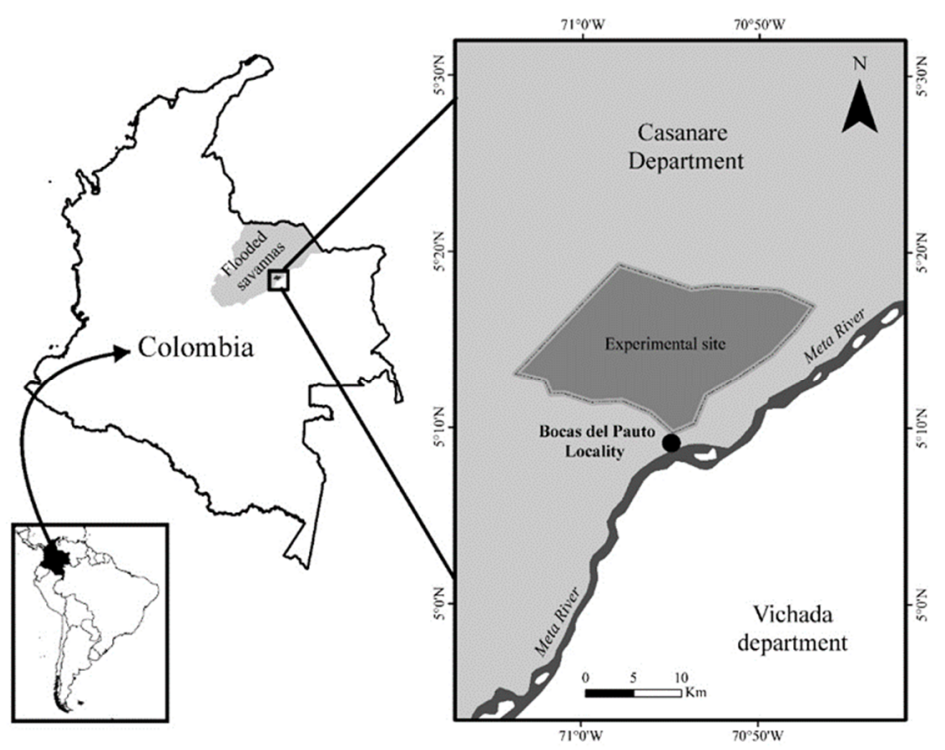

Figure 1. Location of the study site.

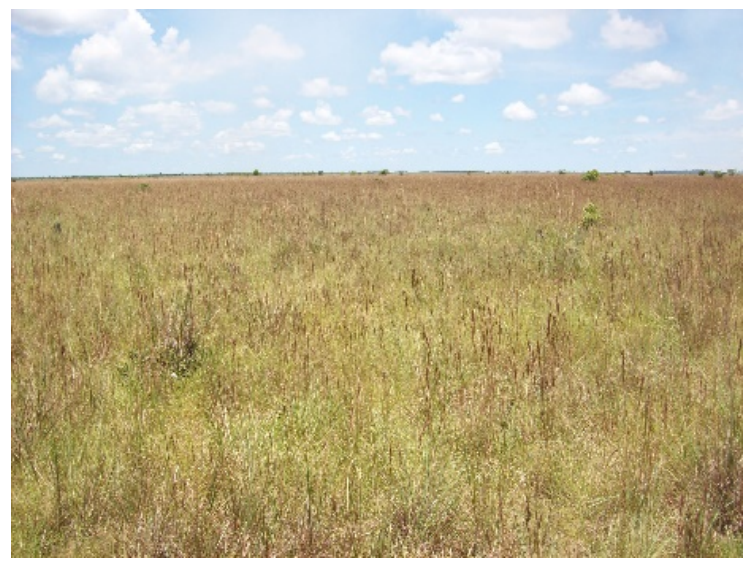

(a)

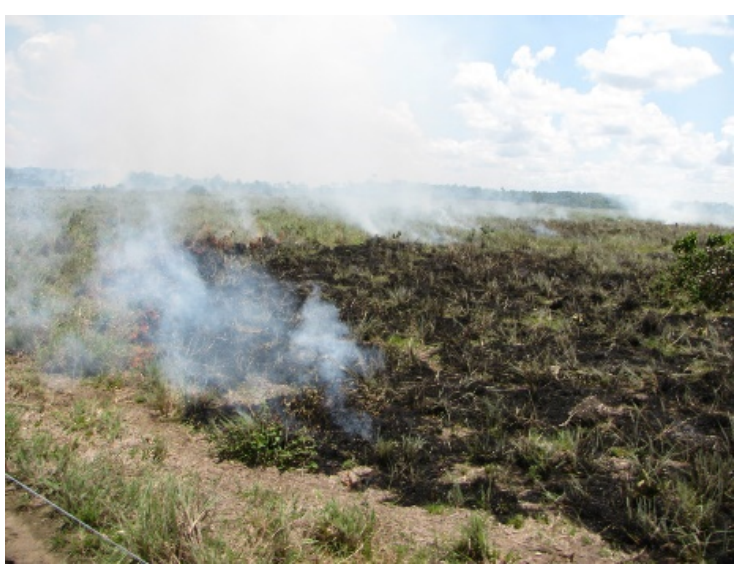

(b)

Figure 2. Cont. 


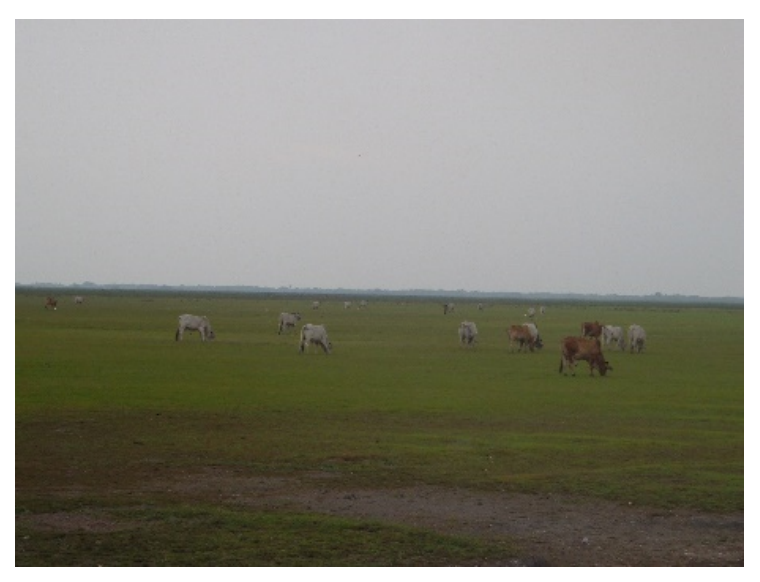

(c)

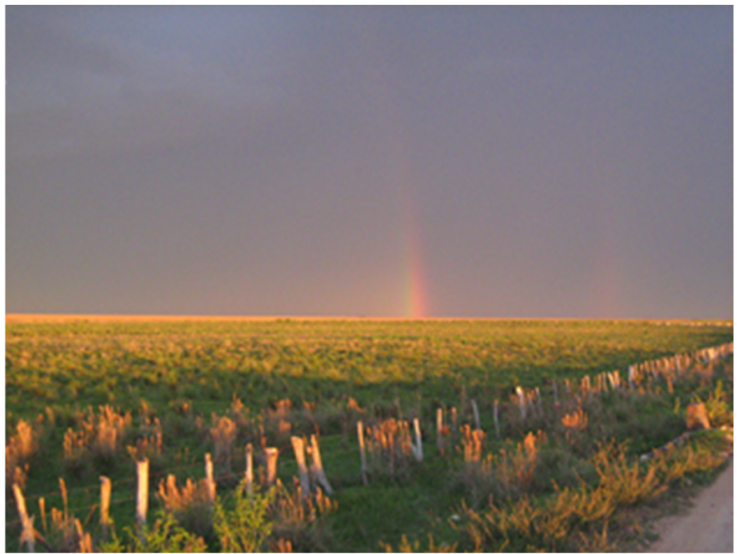

(d)

Figure 2. Examples of cattle grazing and burning management in the study site: (a) savanna with lignified grassland dominated by Andropogon bicornis (graminoid); (b) controlled burning to promote re-growth of savanna vegetation; (c) cattle grazing in post-burn vegetation; (d) savanna vegetation recovery five months after burning and before the start of the rainy season.

\subsection{Treatment Characterization and Data Acquisition}

The experimental site is a flooded savanna that was subjected to annual cattle grazing (Bos indicus $\sim 300 \mathrm{~kg}$ ) and burning (annually, but occasionally more than once per year) for the last ten years. No other relevant anthropic impacts (petroleum exploration, oil-palm plantations or rice cultivations) were identified in historical satellite imagery (Landsat 7 and 8 collection from 2000 to the present, taken from Google Engine at https: / / earthengine. google.com/), which was corroborated with fieldwork visits. We defined three treatments based on cattle stocking rate: $(\mathrm{NG})$ non-grazed = savanna excluded from cattle grazing and burning for at least 5 years; (LS) low stocking rate of cattle = savanna with cattle grazing ( 0.5 ind $\mathrm{ha}^{-1} \mathrm{yr}^{-1}$ ) subjected to annual burns; (HS) high stocking rate of cattle = savanna with cattle grazing ( 1.0 ind $\left.\mathrm{ha}^{-1} \mathrm{yr}^{-1}\right)$ subjected to annual burns. These low and high cattle stocking rates were defined according to Rippstein et al. [27] for grassland in the study region. The last grazing in LS and HS treatments occurred before April 2018 ( 6 months grazing in paddocks). We selected plots of a similar physiognomy and a homogeneous natural savanna area, at least $50 \mathrm{~m}$ from gallery forests or introduced pastures such as Brachiaria spp.

The savanna vegetation of each treatment (NG, LS, and HS) was burned in November 2018. The burning was simultaneously carried out by groups of two people per treatment. Vegetation was studied in 5 plots of $50 \times 50 \mathrm{~m}$ per treatment (NG, LS, and HS). The plots (spatial replicas) were located randomly in each treatment and were permanently marked for the entire study. Animal grazing (domestic and wildlife) was excluded using fences $1 \mathrm{~m}$ high. We conducted vegetation surveys 5 times in each plot (temporal replicas) during the dry season (November 2018 to April 2019), reaching 25 measurements per treatment (5 plots $x 5$ times). The pre-burn survey was performed in November $2018(t 0)$. The first post-burn survey was carried out on the 15th day after burning $(t 1)$, due to the fast growth rate of the vegetation. Post-burn surveys were repeated every 30 days until 105 days after burning ( $t 2$ to $t 4)$. We identified vascular plants (dicots, monocots and ferns) at species level, following Rippstein et al. [27] and Escobar et al. [28]. We characterized vegetation structure (ground cover and height by species, and species richness) and composition (species list, life-form and palatability). Plant species ground cover (\%) in each plot was estimated using a modification of the Braun-Blanquet scale [29], for which 0 indicates absence, and 1 to 5 indicate an abundance-cover range $(<5 \%, 5 \%-25 \%, 25 \%-50 \%, 50 \%-75 \%$, $75-100 \%$, respectively). Ground cover (\%) of bare soil was also estimated using this scale. 
In early measurements, when species could not be taxonomically identified, morphotypes were assigned. In addition, height $(\mathrm{cm})$ of dominant species $(>50 \%$ cover) was estimated measuring the extended leaves. We also defined the life-form of the species (as graminoids, forbs, shrubs and ferns), and the life-cycle (as annual or perennial plants) following Rippstein et al. [27] (Table S1). Plant life-forms were studied because these are closely related to the environmental conditions, showing similar patterns under equivalent impacts (e.g., grazing and fire management) in communities of different regions, which allow comparisons among them, even in different landscapes [30,31]. Finally, plant palatability for cattle (low, middle, and high) was defined for species based on Peñuela et al. [18], although this information does not exist for some species, which were classified as not-reported.

\subsection{Data Analysis}

Covers by life-form and total vegetation (\%) were calculated for each plot and grazing treatment in pre- and post-burn periods. To characterize the relationships between species vegetation cover and grazing treatments, considering the pre- $(t 0)$ and the last post-burn (t4) time, two-way hierarchical cluster analysis was employed, using Ward's method of linkage with Euclidean distance. We also analysed the plot ordination comparing the pre- $(t 0)$ and the last post-burn ( $t 4)$ times, using a non-metric multidimensional scaling (NMDS) with species cover (\%) and Bray-Curtis distance [32]. The significance of each axis was estimated by a Monte Carlo test ( 250 runs). The multivariate statistical differences among groups were tested using a multi-response permutation procedure (MRPP), also with Bray-Curtis distance. All multivariate statistical analyses were performed using PC-ORD [33]. Additionally, t0 bare soil and vegetation ground cover partitioned by life-forms (graminoids, forbs, shrubs) and total were assessed by one-way analyses of variance (ANOVA) using grazing (NG, LS, HS) as the main analysis factor. Likewise, bare soil, vegetation ground cover classified by life-forms and total, as well as height of dominant species, were analysed by two-way ANOVAs considering grazing (NG, LS, HS) and post-burn times $(t 1, t 2, t 3, t 4)$ as main analysis factors. The fern life-form was not analysed by ANOVAs because it was observed in few plots for all grazing treatments. In all cases, Shapiro-Wilk and Levene methods were used to test normality and homogeneity, respectively. When ANOVA assumptions were not met, variables were transformed: (i) in pre-burn analysis, bare soil cover was transformed by $\log (X+1)$; (ii) in post-burn analysis, forb and shrub covers were transformed by $\log (X+1)$, while graminoid cover was transformed by square root. Non-transformed data are shown in Tables. We used the post-hoc Tukey test $(p<0.05)$ to compare mean values. ANOVAs analyses were conducted using Statgraphics software (Statistical Graphics Corp., The Plains, Virginia, USA). Complementary overlapping richness analysis [34] for the whole and the bovinepalatable plants were performed to examine the differences in shared and exclusive species among the three grazing treatments in pre-burn ( $t 0)$ and post-burn ( $t 1$ to $t 4)$ assemblages.

\section{Results}

\subsection{Composition of Vascular Plant Assemblages}

In this study we detected 53 vascular plant species, 31 graminoids, 16 forbs, five shrubs, and only one fern (Table S1). In the whole study, there were only two exotic species, both graminoids (Andropogon bicornis and Imperata brasiliensis). Regarding lifecycle, half of the forbs were annuals (eight species), as well as three graminoids, while the other 42 species were perennials. Concerning palatability, this was not reported for most (27 species, including 13 graminoids, nine forbs, four shrubs and one fern), while seven had high palatability (all graminoids), 13 had medium palatability ( 7 graminoids and 6 forbs), and six had low palatability (four graminoids, one forb and one shrub).

Some species were dominant in cover before and after burning (e.g., Andropogon bicornis in NG), while some species observed in pre-burn were not recorded in post-burn surveys, and vice-versa. Dominant species in cover $(>50 \%)$ were seven native and two exotic species (Table S1): one shrub (Clidemia rubra), six native graminoids (A. leucostachyus, 
Axonopus purpusii, Bulbostylis junciformis, Panicum laxum, P. versicolor, Trachypogon vestitus), and two exotic graminoids (A. bicornis and Imperata brasiliensis). Cluster analysis showed fairly well-defined groups of plots according to the pre- and post-burn assemblages (75\% of the remaining information in the analysis) (Figure 3). Considering the pre-burn assemblages, plots were clearly grouped by grazing treatment; while for the last post-burn time (t4) assemblages, LS and HS were shared, and NG was split into two sub-groups.

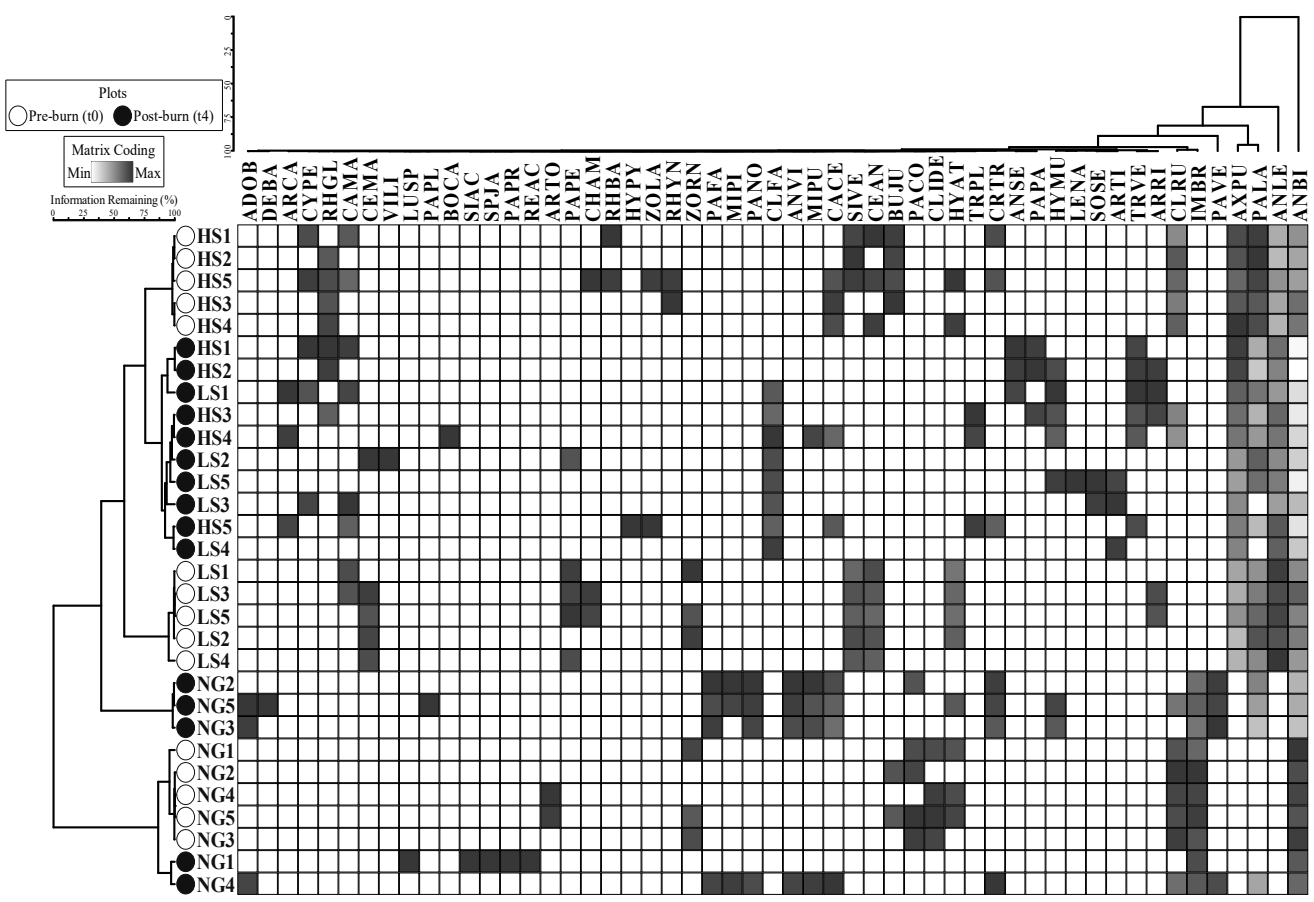

Figure 3. Two-way hierarchical cluster dendrogram showing the composition of vascular plant species (columns) in each plot for different grazing treatments (rows), for the pre- $(t 0)$ and the last post-burn ( $t 4)$ surveys. Greyscale of squares represents the gradient in vegetation cover (\%), where white squares indicate the absence of the species, and dark grey indicates the maximum cover range (75\%-100\%, e.g., for Andropogon bicornis in NG1). NG = non-grazed, LS = low stocking rate, $\mathrm{HS}=$ high stocking rate. Species codes appear in Table S1.

When bovine-palatable species were analysed (Figure 3), some graminoids were not affected by the fires and maintained their cover after the burning, such as A. purpusii and $P$. laxum. In $t 0$, the most representative species were A. bicornis, I. brasiliensis (graminoids) and C. rubra (shrub) for NG, whereas in post-burn these were A. bicornis, I. brasiliensis and $P$. versicolor (graminoids) (Table S2). These results highlighted the dominance and resistance of A. bicornis and I. brasiliensis in pre- and post-burn treatments in non-grazed grasslands. For LS and HS, the dominant species before burning were A. bicornis, A. leucostachyus and P. laxum, while in the post-burn, Andropogon species continued to dominate the area but burning allowed an increase in abundance of other species.

For NMDS, a 3-dimensional solution was recommended (final stress $=5.324$, final instability $=0.001)$, but only the two first axes were graphed (Figure 4): Axis $1(p=0.016)$ and Axis $2(p=0.008)$. NMDS showed two different large groups, one formed by NG plots, and the other by LS-HS plots. The main differences between these groups, mainly split by Axis 2 , were the presence/absence of some species (Imperata brasiliensis, Paspalum conjugatum and Adiantum obliquum were only found in NG, while A. leucostachyus, A. purpusii and Caladium macrotites were characteristic species of grazed plots). Moreover, pre-burn (t0) and post-burn ( $t 4)$ surveys for each grazing treatment also conformed different groups, pre-burn assemblages being less dispersed and conspicuous than post-burn assemblages, which presented greater dispersion. In NG, the five $t 4$ surveys changed in a similar direction compared with t0, although with dissimilar dimension. The changes in LS 
and HS presented more variable directions but quite similar dimensions, the pre-burn assemblages being more compact and different, whereas post-burn assemblages were more dispersed and less differentiated. Axis 1 was strongly associated with the change direction driven by burning in the NG treatment, as well as with the split between LS and HS in pre-burn. Changes in pre- and post-burn times in LS and HS were highlighted by Axis 2, associated mainly with the reduction of cover in many species. MRPP confirmed these patterns, being significant for the analysis $(\mathrm{T}=-7.747, \mathrm{~A}=0.138, p<0.001)$, in the comparison among all grazing treatments within $t 0$ and $t 4$, and in the contrast between the different survey times for each grazing treatment (Table S3). However, marginal differences were observed between LS and HS treatments in $t 4(\mathrm{~T}=-1.848, \mathrm{~A}=0.076, p=0.050)$.

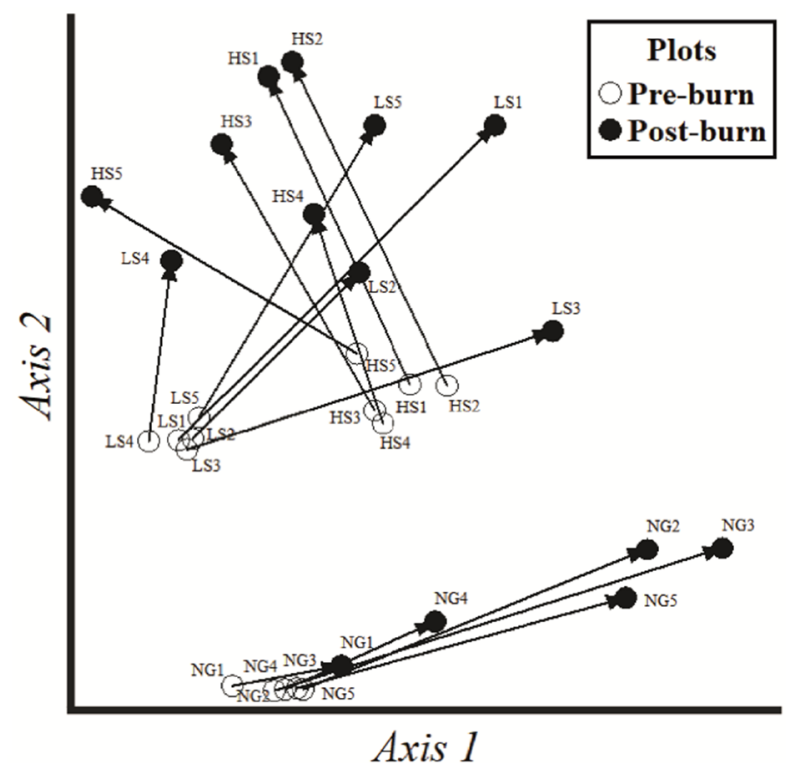

(a)

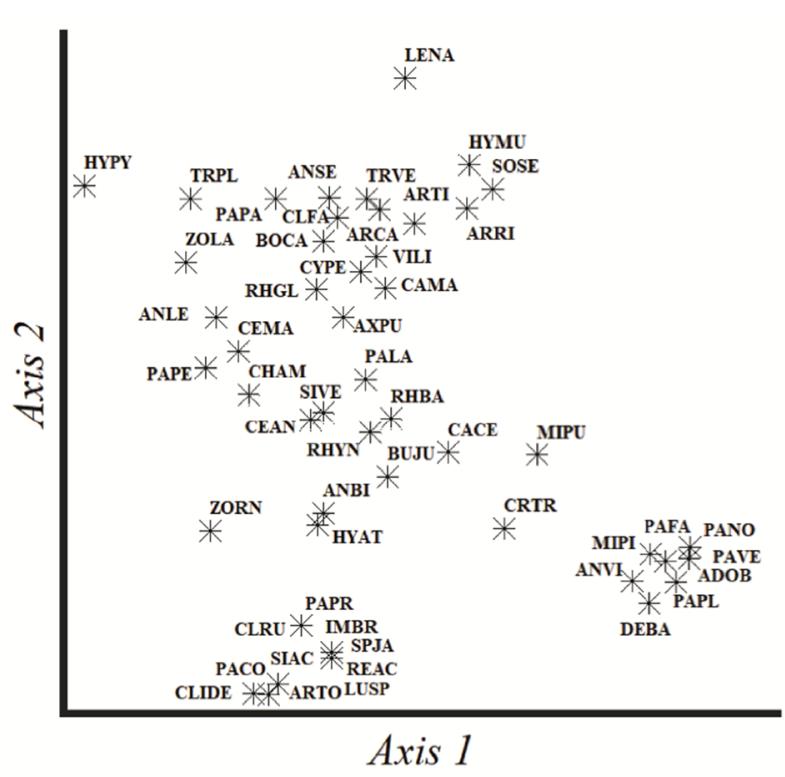

(b)

Figure 4. Plot (a) and plant species (b) ordination by non-metric multidimensional scaling (NMDS) based on a matrix of vascular plant species cover, comparing the pre- $(t 0)$ and the last post-burn ( $t 4)$ surveys in every grazing treatment. Vectors show the magnitude and the direction of changes between times for the same plot. NG = non-grazed, LS = low stocking rate, HS = high stocking rate. Species codes appear in Table S1.

\subsection{Vegetation Response to Differential Cattle Stocking Rates and Burning}

In pre-burn assemblages $(t 0)$, total vegetation cover $(\%)$ was similar for all treatments $(>90 \%$ of cover), but significant differences were found between HS (with lower values) compared with NG and LS (both with greater similar values, Table 1). On the contrary, HS presented significantly higher bare soil cover $(>5 \%)$ than LS and NG treatments. Graminoids were dominant compared with other life-forms in $t 0$, and significant differences were found among grazing treatments, with LS > NG > HS. On the other hand, shrub cover was greater in NG than HS than LS, while forbs (e.g., legumes) were detected in greater abundance for HS, but without differences in the other grazing treatments. 
Table 1. One-way analyses of variance (ANOVAs) for bare soil and vascular plant ground cover (\%) at the pre-burn (t0) time, classified according to their life-form (graminoid, forb, shrub) and for the total vegetation, where grazing ( $\mathrm{NG}=$ non-grazed, $\mathrm{LS}=$ low stocking rate, $\mathrm{HS}=$ high stocking rate) is the main analysis factor. Bare soil was $\log (X+1)$ transformed to accomplish the assumptions of ANOVA, but non-transformed data are shown.

\begin{tabular}{cccccc}
\hline Treatment & Bare Soil & Graminoid & Forb & Shrub & $\begin{array}{c}\text { Total } \\
\text { Vegetation }\end{array}$ \\
\hline NG & $0.0 \mathrm{a}$ & $89.9 \mathrm{~b}$ & 1.0 & $9.1 \mathrm{c}$ & $100.0 \mathrm{~b}$ \\
LS & $2.3 \mathrm{a}$ & $96.0 \mathrm{c}$ & 1.7 & $0.0 \mathrm{a}$ & $97.7 \mathrm{~b}$ \\
HS & $8.7 \mathrm{~b}$ & $85.9 \mathrm{a}$ & 2.9 & $2.5 \mathrm{~b}$ & $91.3 \mathrm{a}$ \\
$F(p)$ & $12.29(0.001)$ & $28.07(<0.001)$ & $1.92(0.189)$ & $71.31(<0.001)$ & $12.29(0.001)$ \\
\hline
\end{tabular}

$F(p)=$ Fisher's test and significance between brackets. Different letters for each column show differences using Tukey test at $p<0.05$.

Comparing before and after burning, total vegetation cover decreased post-burn to $40 \%-55 \%$ values. Cover of graminoids, as well as total vegetation, was significantly similar between NG and LS in post-burn comparisons, and higher than HS (Table 2). Bare soil followed the contrary pattern, with significant and lower cover in NG and LS than in HS. Forb cover was similar for all treatments, and shrubs maintained higher cover in NG and HS than in LS, but significantly lower regarding pre-burn values. Ferns (e.g., Adiantum obliquum) were detected in NG since $t 2$, but were not recorded during pre-burn samplings. Considering the burning time points, bare soil decreased, while total vegetation and graminoid covers increased from $t 1$ to $t 4$. Forbs and shrubs also increased with time, but significant differences were detected only for $t 4$. No significant interactions among grazing (NG, LS, HS) and post-burn times $(t 1, t 2, t 3, t 4)$ were observed, except for shrubs $(p=0.032)$. Regarding the height of dominant plants, it followed the gradient NG > LS > HS in grazing treatments and, as was expected, increased with time (Table 3), being greater in some species (Table S2). Finally, there were no significant interactions among grazing (NG, LS, HS) and post-burn times $(t 1, t 2, t 3, t 4)$ in height.

Table 2. Two-way ANOVAs for bare soil and vascular plant ground cover (\%) classified according to their life-form (graminoid, forb, shrub) and for the total vegetation, where (A) grazing (NG = non-grazed, LS = low stocking rate, $\mathrm{HS}=$ high stocking rate) and (B) post-burn times $(t 1 \ldots t 4)$ were the main analysis factors. Interactions $\mathrm{A} \times \mathrm{B}$ are also analysed. Forbs and shrubs were $\log (\mathrm{X}+1)$ transformed to accomplish assumptions of ANOVA, while graminoid was square-root transformed, but non-transformed data are shown. Average cover values for fern variables were added as complementary information.

\begin{tabular}{|c|c|c|c|c|c|c|}
\hline Factors & Bare Soil & Graminoid & Forb & Shrub & Fern & Total Vegetation \\
\hline \multicolumn{7}{|c|}{ A: Treatments } \\
\hline NG & $44.4 \mathrm{a}$ & $53.5 \mathrm{~b}$ & 1.4 & $0.4 \mathrm{~b}$ & 0.3 & $53.3 \mathrm{~b}$ \\
\hline LS & $47.0 \mathrm{a}$ & $51.2 \mathrm{~b}$ & 1.8 & $0.0 \mathrm{a}$ & 0.0 & $52.9 \mathrm{~b}$ \\
\hline HS & $59.6 \mathrm{~b}$ & $39.7 \mathrm{a}$ & 0.5 & $0.2 \mathrm{ab}$ & 0.0 & $40.4 \mathrm{a}$ \\
\hline$F(p)$ & $15.82(<0.001)$ & $14.45(<0.001)$ & $2.86(0.067)$ & $8.56(0.001)$ & - & $16.27(<0.001)$ \\
\hline \multicolumn{7}{|c|}{ B: Post-burn time points } \\
\hline$t 1$ & $72.9 \mathrm{~d}$ & $27.0 \mathrm{a}$ & $0.1 \mathrm{a}$ & $0.0 \mathrm{a}$ & 0.0 & $26.6 \mathrm{a}$ \\
\hline$t 2$ & $57.3 \mathrm{c}$ & $41.8 \mathrm{~b}$ & $0.7 \mathrm{a}$ & $0.1 \mathrm{ab}$ & 0.1 & $42.2 \mathrm{~b}$ \\
\hline t3 & $41.5 \mathrm{~b}$ & $57.0 \mathrm{c}$ & $1.1 \mathrm{a}$ & $0.3 \mathrm{ab}$ & 0.1 & $57.3 \mathrm{c}$ \\
\hline$t 4$ & $29.7 \mathrm{a}$ & $66.7 \mathrm{~d}$ & $2.9 \mathrm{~b}$ & $0.4 \mathrm{~b}$ & 0.3 & $69.6 \mathrm{~d}$ \\
\hline$F(p)$ & $63.35(<0.001)$ & $60.48(<0.001)$ & $7.35(0.004)$ & $4.31(0.009)$ & - & $77.90(<0.001)$ \\
\hline \multicolumn{7}{|c|}{ Interaction: $\mathrm{A} \times \mathrm{B}$} \\
\hline$F(p)$ & $1.72(0.136)$ & $1.55(0.182)$ & $1.12(0.367)$ & $2.54(0.032)$ & - & $2.00(0.084)$ \\
\hline
\end{tabular}

$F(p)=$ Fisher's test and significance between brackets. Different letters for each column show differences using Tukey test at $p<0.05$. 
Table 3. Two-way ANOVAs for height $(\mathrm{cm})$ of dominant plant species, where (A) grazing $(\mathrm{NG}=$ non-grazed, $\mathrm{LS}=$ low stocking rate, $\mathrm{HS}=$ high stocking rate) and $(\mathrm{B})$ post-burn times $(t 1$ $\ldots t 4)$ were the main analysis factors. Interactions $\mathrm{A} \times \mathrm{B}$ are also analysed. Species height from $t 0$ to t4 is presented in Table S2.

\begin{tabular}{cc}
\hline Factors & Height \\
\hline A: Treatments & \\
NG & $44.0 \mathrm{c}$ \\
LS & $30.3 \mathrm{~b}$ \\
HS & $21.7 \mathrm{a}$ \\
$F(p)$ & $31.64(<0.001)$ \\
B: Post-burn times & $20.2 \mathrm{a}$ \\
$t 1$ & $26.3 \mathrm{a}$ \\
$t 2$ & $35.3 \mathrm{~b}$ \\
$t 3$ & $46.1 \mathrm{c}$ \\
$t 4$ & $23.90(<0.001)$ \\
$F(p)$ & $2.00(0.083)$ \\
\hline Interaction: A $\times \mathrm{B}$ & $(p)$
\end{tabular}

$\overline{F(p)=\text { Fisher's test and significance between brackets. Different letters for each column show differences using }}$ Tukey test at $p<0.05$.

\subsection{Exclusive and Shared Plant Species among Grazing Treatments}

In the study area, pre-burn (t0) time showed a total richness of 26 species (Figure S1) across all grazing treatments, sharing only two $(8 \%)$ species among the three treatments. The higher number of exclusive species was found in HS (seven species) followed by NG (four species) and LS (three species), while there were seven species shared only between HS and LS, two between HS and NG, and only one between LS and NG. Post-burn t4, total richness reached 44 species, but only three species were shared among the three treatments. NG presented the higher number of exclusive species (16 species), contrary to the outputs found in $t 0$, with six exclusive species in HS and four in LS. NG doubled the number of species shared only with HS compared with $t 0$ (four species), without any species shared between NG and LS. The number of species shared only between LS and HS also increased (from seven to 11 species) in the post-burn comparisons.

Bovine-palatable species richness (Figure S1) pre-burn was higher in LS and HS (seven species each) than in NG (two species), whereas LS and HS had a higher number of shared (five) and exclusive (two each) species, and NG had only one exclusive and one shared species. However, in post-burn ( $t 4)$ comparisons, this trend changed, NG presenting more palatable species richness (14 species) than LS and HS (12 and 11 species, respectively), whereas more palatable species (eight species) were shared between LS and HS, but more exclusive species also appeared in NG (10 species) while exclusive species in LS were four and in HS only one.

\section{Discussion}

\subsection{Vascular Plant Assemblages before and after Burning}

Our result showed the dominance and resistance of Andropogon bicornis and Imperata brasiliensis in non-grazed grasslands before and after burning, as was reported by Peñuela et al. [18]. In addition, Panicum versicolor was favored by burning, probably due to the removal of competition from other grass species with dense foliage (e.g., A. bicornis), facilitating the growth of suppressed species in the pre-burn condition, e.g., Adiantum obliquum (fern), Hyptis mutabilis (forb), Leptocoryphium lanatum (graminoid), and Sida acuta (shrub). These changes in composition and dominance of species are important for land management, due to their contribution to the evidence the changes induced by burning could increase local diversity, e.g., I. brasiliensis is known for its rapid post-fire recovery and often becomes dominant after disturbances [35]. Related to bovine-palatable species, our findings were coincident with Rippstein et al. [27] who suggested that, under continuous forage, 
Andropogon species (dominant or codominant in grasslands) reduce their covers whereas Axonopus species increase. Previous studies have reported similar species suppression due to higher cattle stocking rates in temperate grassland of the northern hemisphere [13,36].

Pre-burn assemblage vegetation in grazed areas (e.g., LH and HS) was more similar than vegetation assemblages in non-grazed areas, as was graphically shown in NMDS and correlated, for example, with higher percentage of Panicum laxum and A. purpusii (graminoids) in pre-burn treatments. This can be influenced by continuous bovine foraging which, in synergy with the impacts of burning, stimulates the development of other species. This could be the case of A. purpusii, for which burning would appear to have influenced growth more than with other species, homogenizing the vegetation along the way. Previous studies in other grasslands in the northern hemisphere have reported that cattle show significant preference for recently burned patches, and this preference declines with time $[36,37]$. The same trend was observed for tropical savannas with pines, where fire suppression management is implemented using cattle grazing to reduce fire risk [38]. Regarding stocking rate, previous studies have shown that overgrazing of savannas is related to the size of the animal and grazing habits $[27,39]$ and not only to the number of animals. Therefore, many cattle and management characteristics must be considered in the evaluation of their impacts on plant assemblages. Grazing with cattle could help conservation, as shown by Török et al. [13] for other grassland landscapes.

\subsection{The Effects of Burning and Previous Grazing Intensity on Vegetation Composition and Structure}

Differences in plant assemblages in pre- and post-burn surveys were detected among the different cattle stocking rates (NG, LS, HS), as well as in vegetation and bare soil cover (Tables 1 and 2). This agreed with Rippstein et al. [27] in areas with high cattle stocking rates. As was expected, graminoid species (e.g., A. bicornis) were dominant in pre-burn surveys. Moreover, a greater presence of forbs was detected in LS and HS. The higher shrub cover for NG in $t 0$ indicates a recovery of woody vegetation without cattle grazing and fire, as was reported previously for other authors $[7,23]$. This positive effect of fire suppression on woody cover has been widely studied during recent years $[3,4,6]$. Abreu et al. [4] suggested that fire suppression was associated with acute species loss, as they observed in flooded savanna specialist species in the Brazilian Cerrado. The detection of some ferns after burning in $t 2$ in NG, not previously recorded in pre-burn treatments, could be due to ferns usually requiring moderate fire to release apical dominance and stimulate bud break [40]. Therefore, burning favors fern growth in the absence of cattle grazing.

For all pre- and post-burn time treatments, the bare soil cover decreases as the graminoid cover increases from $t 1$ to $t 4$, with a quick increment of graminoid richness. A similar trend of cover recovery was observed for forbs and ferns, but in a lower proportion. Shrubs were not recorded in LS (pre- and post-burn), due to ranchers removing shrubs with low palatability to enlarge and promote cover of graminoids for cattle grazing in traditional savanna management. During $t 3$ and $t 4$, the three grazing treatments show a significant increase in total plant cover $(>50 \%)$. This rapid cover increase could be explained by the abundant rainfalls at the end of the dry-rainy transition period that stimulate the growth of the savanna vegetation [23,24]. Huertas Herrera et al. [25] show that flood and drought events are decisive for land use because the forage biomass depends on the dynamics of the soil water, and burning management depends on the soil moisture. In addition, the ashes generated after burning act as self-fertilizer for the plants in combination with rainfall, as was reported by Moog [41]. Huertas Ramírez [42] suggests that burning could improve the regrowth of plants of high nutritional quality for cattle.

Regarding the height of dominant plants, natural grasslands with different cattle stocking rates presented different heights, even when dominant species presented the same behaviour after fires. This suggests that the post-burn time did not increase or decrease the height of the species more than the expected growth across the season. In $t 0, A$. bicornis presented the greatest height for all treatments. Such results highlight the strategy followed by the Andropogon genus (including one exotic species, A. bicornis), which can 
be explained by its graminoid life-form (e.g., dense tufts) and foliar extension which may form upright culms that reach up to $3 \mathrm{~m}$ in height [23]. Previous studies in the savanna indicate that biomass is related to soil water availability, and leaf nutrient content to soil fertility $[27,43]$. Trampling, soil compaction and changes in species composition due to selective grazing are also drivers of change [36,38]. The smaller heights recorded for HS could be explained by the nutrient losses from annual burning. Besides, some species are sensitive to cattle trampling [43,44], e.g., HS evidenced a predominance of Paspalum parviflorum and Trachypogon vestitus more than LS (Table S2). This result indicates that cattle trampling by Bos indicus $(\sim 300 \mathrm{~kg})$ had more significant impact reduction than fire on some graminoids of erect growth in dense tufts. However, since cattle trampling was performed here before fires, this effect could depend on the time since grazing occurred. We can conclude that greater growth of species in NG grasslands can be influenced by burning due to the improvement in nutrient availability due to ashes (that increase soil fertility), as was reported by Hernández and López [45].

\subsection{The Role of Grazing and Burning Management}

LS and HS treatments shared more species than the other treatments, where several bovine-palatable species occurred in LS and HS, with many exclusive species in NG. After burning, several palatable species increased in the studied treatments. Early studies showed that fires in savanna stimulate the growth of bovine-palatable plants promoted by the management of local people [6,7], e.g., adequate levels of burning and grazing favor $A$. purpusii and Paspalum spp. [25], highly palatable species for cattle [18]. Moreover, burning improves the diet of bovines in most lignified grasslands, such as T. vestitus (graminoid), encouraging the forage of fewer appetizing species, such as A. bicornis, L. lanatum and A. leucostachyus (graminoids) $[17,18]$. Therefore, our results agree that burning improves the forage offer to cattle, observing an increase in the richness of palatable species over time.

The description of short-term consequences of different grazing and burning histories according to different stocking rates could be useful for grazing management, defining the benefits and trade-offs of grazing for a sustainable management strategy in savannas and other tropical ecosystems, which is widely debated in ecology and conservation biology $[9,17,18,25,27,44]$. In savanna ecosystems, cattle grazing and fire management may represent opportunities for combined nature conservation and production. In this context, our work could bring information for decision-makers on the ecological role of grazing and burning. For example, division of paddocks for different grazing rates could improve control in recovery, managing the cover and height of native-palatable species through the increasing or decreasing of the stocking rate in each paddock. Grassland productivity could also be preserved with controlled burning, avoiding the dominance of exotic and less palatable species, which could be dominant in fire restricted and non-grazed grasslands. Post-burn recovery time (from $t 3$ to $t 4$ ) of grasslands is crucial because this defines the periods of occurrence and recovery of native plants with special interest to producers (e.g., A. purpusii, graminoid). This can lead to the creation of beneficial grassland characteristics both for conservation and cattle production. Mapiye et al. [46] also describe the ecological role of grazing and burning for local conservation and production systems in the savannas of southern Africa, e.g., burning controls unwanted and undesirable plant species on rangelands and enhances cattle productivity. Huertas Herrera et al. [25] also note that burning and grazing provide food for wildlife. However, burning can affect fire-sensitive species (e.g., palms, fishes, mammals), therefore, it is crucial to protect and maintain natural area legacies as a home for native wildlife $[17,18,25]$. In addition, the effective management of fire on the savannas could be useful to guide conservation strategy programs in natural grasslands (e.g., opportunities for carbon dioxide and uncontrolled wildfire mitigation) through the rational use of burning, as Lipsett-Moore et al. [11] suggested for countries in Africa, South America, Australia and Papua New Guinea. In tropical savannas, carbon mitigation programs promote forest cover, but not direct benefits for conservation [4]. 
Cattle are usually assumed to have adverse effects on nature conservation, but several studies have also reported positive and neutral effects $[9,44,47]$.

\section{Conclusions}

In the study site, savanna vegetation cover and height quickly recover after burning, despite different cattle stocking rates. However, substantial changes occur in vegetation composition and cover of several life-forms after burning, and due to previous grazing or the intensity of grazing. The right choice of both factors would benefit cattle production and savanna conservation, due to the fact that many native-palatable species can be maintained after fire. Besides, the exclusion of grazing in some areas can contribute to the survival of unique species in the savanna. Some exotic and low bovine-palatable species (e.g., A. bicornis) show resistance to grazing both in cover and height. Areas with grazing subjected to fire have higher representativeness of palatable vascular plants than non-grazed areas, mainly after fires. However, before burning, a high stocking rate of bovines favors the cover of some low height species (e.g., A. purpusii, a very palatable species), as well as bare soil ground cover. The assemblage of the species is different before burning according to the previous presence or not of cattle, as well as its stocking rate. After burning, the assemblages become more heterogeneous than under grazing (e.g., there is a greater plant assemblage dispersion in post-burn areas). This combined effect of fire and grazing as environmental drivers could be important for land management, particularly the differences between low and high-intensity grazing. These outputs also highlight the need to explore new alternatives for savanna management that aim to reconcile cattle production and biodiversity conservation, e.g., cattle activities on vegetation communities with palatable native plants could represent conservation and production integration scenarios which contribute to reduce the use of burning, since bovines favor the establishment of palatable species.

Supplementary Materials: The following are available online at https:/ /www.mdpi.com/2073-4 45X/10/2/108/s1, Figure S1: Overlapping representation of exclusive and shared vascular plant species among treatments in pre- $(t 0)$ and post-burn ( $t 4)$ times. The numbers displayed in the diagrams correspond to species richness, considering: (a) total species, and (b) palatable species. $\mathrm{NG}=$ non-grazed, $\mathrm{LS}=$ low stocking rate, $\mathrm{HS}$ = high stocking rate; Table S1: Species list of vascular plants classified by life-form (graminoid, fern, forb and shrub) and taxonomic group (dicots, monocots and pteridophyta), showing code, origin ( $\mathrm{N}=$ native, $\mathrm{E}=$ exotic), life-cycle $(\mathrm{P}=$ perennial, $\mathrm{A}=$ annual $)$, palatability ( $\mathrm{NR}=$ no-reported, $\mathrm{L}=$ low, $\mathrm{M}=$ middle, $\mathrm{H}=\mathrm{High}$ ) and presence in plots for the studied treatments ( $\mathrm{NG}=$ non-grazed, $\mathrm{LS}=$ low stocking rate, $\mathrm{HS}=$ high stocking rate) in pre- $(\mathrm{t} 0)$, and post-burn $(\mathrm{t} 1, \mathrm{t} 2, \mathrm{t} 3, \mathrm{t} 4)$ times; Table S2: Height $(\mathrm{cm})$ of dominant species $(>50 \%$ cover) for different treatments ( $\mathrm{NG}=$ non-grazed, $\mathrm{LS}=$ low stocking rate, $\mathrm{HS}=$ high stocking rate) in pre( $\mathrm{t} 0$ ) and post-burn ( $\mathrm{t} 1, \mathrm{t} 2, \mathrm{t} 3$, t4) times; Table S3: Multi-Response Permutation Procedures (MRPP) results evaluating differences among grazing treatments $(\mathrm{NG}=$ non-grazed, $\mathrm{LS}=$ low stocking rate, $\mathrm{HS}=$ high stocking rate) in pre- (t0) and post-burn (t4) times.

Author Contributions: Conceptualization, A.H.H., B.L.G.B.B., H.H.R.; methodology, B.L.G.B.B.; formal analysis, A.H.H., M.D.R.T.-M., M.V.L.; investigation, A.H.H., B.L.G.B.B., H.H.R.; data curation, A.H.H., H.H.R.; project administration, H.H.R.; writing-original draft, A.H.H., M.D.R.T.-M., M.V.L., G.J.M.P. All authors have read and agreed to the published version of the manuscript.

Funding: This research received no external funding.

Institutional Review Board Statement: Not applicable.

Informed Consent Statement: Not applicable.

Data Availability Statement: Not applicable.

Acknowledgments: We thank the cattle ranchers of Trinidad, especially to the Asociación de Ganaderos de Bocas del Pauto for the logistic assistance. We are grateful to Cunaguaro Foundation research collaboration. We also thank to María Lucila Reyes, President of the Comité Departamental de Ganaderos de Casanare for their technical support. 
Conflicts of Interest: The authors declare no conflict of interest.

\section{References}

1. Mbow, C.; Nielsen, T.T.; Rasmussen, K. Savanna fires in east-central Senegal: Distribution patterns, resource management and perceptions. Hum. Ecol. 2000, 28, 561-583. [CrossRef]

2. Mistry, J.; Berardi, A.; Andrade, V.; Krahô, T.; Krahô, P.; Leonardos, O. Indigenous fire management in the cerrado of Brazil: The case of the Krahô of Tocantíns. Hum. Ecol. 2005, 33, 365-386. [CrossRef]

3. Burgess, E.E.; Moss, P.; Haseler, M.; Maron, M. The influence of a variable fire regime on woodland structure and composition. Int. J. Wildland Fire 2015, 24, 59-69. [CrossRef]

4. Abreu, R.C.; Hoffmann, W.A.; Vasconcelos, H.L.; Pilon, N.A.; Rossatto, D.R.; Durigan, G. The biodiversity cost of carbon sequestration in tropical savanna. Sci. Adv. 2017, 3, e1701284. [CrossRef] [PubMed]

5. Bowman, D.M.; Balch, J.K.; Artaxo, P.; Bond, W.J.; Carlson, J.M.; Cochrane, M.A.; D'Antonio, C.M.; DeFries, R.S.; Doyle, J.C.; Harrison, S.P. Fire in the Earth system. Science 2009, 324, 481-484. [CrossRef]

6. Rodríguez-Trejo, D.A.; Pausas, J.G.; Miranda-Moreno, A.G. Plant responses to fire in a Mexican arid shrubland. Fire Ecol. 2019, 15, 11. [CrossRef]

7. Rodríguez, I. Pemon perspectives of fire management in Canaima National Park, southeastern Venezuela. Hum. Ecol. 2007, 35, 331-343. [CrossRef]

8. Romero-Ruiz, M.; Flantua, S.; Tansey, K.; Berrio, J. Landscape transformations in savannas of northern South America: Land use/cover changes since 1987 in the Llanos Orientales of Colombia. App. Geo. 2012, 32, 766-776. [CrossRef]

9. Hoogesteijn, A.; Hoogesteijn, R. Cattle ranching and biodiversity conservation as allies in South America's flooded savannas. Great Plains Res. 2010, 20, 37-50. Available online: http:/ / digitalcommons.unl.edu/greatplainsresearch (accessed on 10 March 2020).

10. Carriazo, F.; Labarta, R.; Escobedo, F.J. Incentivizing sustainable rangeland practices and policies in Colombia's Orinoco region. Land Use Policy 2019, 95, 104203. [CrossRef]

11. Lipsett-Moore, G.J.; Wolff, N.H.; Game, E.T. Emissions mitigation opportunities for savanna countries from early dry season fire management. Nat. Commun. 2018, 9, 2247. [CrossRef] [PubMed]

12. Phalan, B.; Onial, M.; Balmford, A.; Green, R.E. Reconciling food production and biodiversity conservation: Land sharing and land sparing compared. Science 2011, 333, 1289-1291. [CrossRef]

13. Török, P.; Valkó, O.; Deák, B.; Kelemen, A.; Tóthmérész, B. Traditional cattle grazing in a mosaic alkali landscape: Effects on grassland biodiversity along a moisture gradient. PLoS ONE 2014, 9, e97095. [CrossRef] [PubMed]

14. Török, P.; Hölzel, N.; van Diggelen, R.; Tischew, S. Grazing in European open landscapes: How to reconcile sustainable land management and biodiversity conservation? Agr. Ecosys. Environ. 2016, 234, 1-4. [CrossRef]

15. Malan, J.-A.C.; Flint, N.; Jackson, E.L.; Irving, A.D.; Swain, D.L. Environmental factors influencing cattle's water consumption at offstream watering points in rangeland beef cattle. Livest. Sci. 2020, 231, 103868. [CrossRef]

16. Treydte, A.C.; Baumgartner, S.; Heitkönig, I.M.A.; Grant, C.C.; Getz, W.M. Herbaceous Forage and Selection Patterns by Ungulates across Varying Herbivore Assemblages in a South African Savanna. PLoS ONE 2013, 8, e82831. [CrossRef] [PubMed]

17. Peñuela, L.; Fernández, A.; Castro, F.; Ocampo, A. Uso y Manejo de Forrajes Nativos en la Sabana Inundable de la Orinoquía, 1st ed.; The Nature Conservancy: Bogotá, Colombia; Fundación Horizonte verde: Bogotá, Colombia; Fundación Biodiversa de España y Corporinoquía: Bogotá, Colombia, 2011; pp. 4-66.

18. Peñuela, L.; Solano, C.; Ardila, V.; Galán, S. Sabana Inundable y Ganadería, Opción Productiva de Conservación en la Orinoquia, 1st ed.; Fundación Natura: Bogotá, Colombia, 2014; pp. 27-230.

19. Olson, D.M.; Dinerstein, E. The Global 200: Priority ecoregions for global conservation. Ann. Missouri. Bot. Gard. 2002, 89, 199-224. [CrossRef]

20. Hurtley, S. Surveying Savannas. Science 2014, 343, 460. [CrossRef]

21. Robinson, T.P.; Wint, G.R.W.; Conchedda, G.; Van Boeckel, T.P.; Ercoli, V.; Palamara, E.; Cinardi, G.; D’ Aietti, L.; Hay, S.I.; Gilbert, M. Mapping the Global Distribution of Livestock. PLoS ONE 2014, 9, e96084. [CrossRef]

22. Gilbert, M.; Nicolas, G.; Cinardi, G.; Van Boeckel, T.P.; Vanwambeke, S.O.; Wint, G.R.W.; Robinson, T.P. Global distribution data for cattle, buffaloes, horses, sheep, goats, pigs, chickens and ducks in 2010. Sci. Data 2018, 5, 180227. [CrossRef]

23. Blydenstein, J. Tropical Savanna Vegetation of the Llanos of Colombia. Ecology 1967, 48, 1-15. [CrossRef]

24. Esquivel, A.; Llanos-Herrera, L.; Agudelo, D.; Prager, S.D.; Fernandes, K.; Rojas, A.; Valencia, J.J.; Ramirez-Villegas, J. Predictability of seasonal precipitation across major crop growing areas in Colombia. Clim. Serv. 2018, 12, 36-47. [CrossRef]

25. Huertas Herrera, A.; Baptiste Ballera, B.L.G.; Toro Manríquez, M.; Huertas Ramírez, H. Manejo de la quema de pastizales de sabana inundable: Una mirada del pueblo originario Sáliva en Colombia. Chungará 2019, 51, 1. [CrossRef]

26. FAO-UNESCO. Soil Map of the World: Revised Legend. World Soil Resources Report 60; Food and Agriculture Organization of the United Nations: Rome, Italy, 1988.

27. Rippstein, G.; Escobar, G.; Motta, F. Agroecología y Biodiversidad de las Sabanas en los Llanos Orientales de Colombia, 1st ed.; CIAT: Cali, Colombia, 2001.

28. Escobar, E.; Belarcázar, J.; Rippstein, G. Clave de las Principales Plantas de Sabana de la Altillanura de los Llanos Orientales en Carimagua, Meta, Colombia, 1st ed.; CIAT: Cali, Colombia, 1993. 
29. Braun-Blanquet, J. Fitosociología: Bases Para el Estudio de las Comunidades Vegetales; Ed Blume: Madrid, España, 1979.

30. Adamson, R.S. The Classification of Life-Forms of Plants. Bot. Rev. 1939, 5, 546-561. [CrossRef]

31. Gimingham, C.H. The Use of Life Form and Growth Form in the Analysis of Community Structure as Illustrated by a Comparison of Two Dune Communities. J. Ecol. 1951, 39, 396-406. [CrossRef]

32. ter Braak, C.J.; Šmilauer, P. Topics in constrained and unconstrained ordination. Plant. Ecol. 2015, 216, 683-696. [CrossRef]

33. McCune, B.; Mefford, M.J. Multivariate Analysis of Ecological Data, Version 4.0; MjM software Design: Gleneden Beach, OR, USA, 1999.

34. Willott, S.J. The effects of selective logging on the distribution of moths in a Bornean rainforest. Phil. Trans. R Soc. Lond. B 1999, 354, 1783-1790. [CrossRef]

35. César, R.G.; Viani, R.A.G.; Silva Candido da, M.; Brancalion, P.H.S. Does a native grass (Imperata brasiliensis Trin.) limit tropical forest restoration like an alien grass (Melinis minutiflora P. Beauv.)? Trop. Conserv. Sci. 2014, 7, 639-656. [CrossRef]

36. Venter, Z.S.; Hawkins, H.-J.; Cramer, M.D. Cattle don't care: Animal behaviour is similar regardless of grazing management in grasslands. Agr. Ecosys. Environ. 2019, 272, 175-187. [CrossRef]

37. Powell, J.; Martin, B.; Dreitz, V.J.; Allred, B.W. Grazing Preferences and Vegetation Feedbacks of the Fire-Grazing Interaction in the Northern Great Plains. Rangel. Ecol. Manag. 2018, 71, 45-52. [CrossRef]

38. Braasch, M.; García-Barrios, L.; Ramírez-Marcial, N.; Huber-Sannwald, E.; Cortina-Villar, S. Can cattle grazing substitute fire for maintaining appreciated pine savannas at the frontier of a montane forest biosphere-reserve? Agr. Ecosys. Environ. 2017, 250, 59-71. [CrossRef]

39. Stringham, T.K.; Krueger, W.C.; Shaver, P.L. State and transition modeling: An ecological process approach. J. Range. Manag. 2003, 56, 106-113. [CrossRef]

40. Roos, K.; Rollenbeck, R.; Peters, T.; Bendix, J.; Beck, E. Growth of tropical bracken (Pteridium arachnoideum): Response to weather variations and burning. Invas. Plant. Sci. Manag. 2010, 3, 402-411. [CrossRef]

41. Moog, F. Forage and Legumes as Protein Supplements for Pasture Based Systems. Feeding Dairy Cows in the Tropics; Food and Agriculture Organization of the United Nations: Bangkok, Thailand, 1991.

42. Huertas Ramírez, H. Digestibilidad in vitro de las gramíneas nativas Axonopus purpussi, Metz y Trachypogon vestitus, Anders en suelos de sabana de los Llanos Orientales. Master's Thesis, Universidad Nacional de Colombia, Bogotá, Colombia, 1977.

43. Baruch, Z. Trachypogon plumosus (POACEAE), un caso de alta diversidad interpoblacional en sabanas neotropicales. Interciencia 2005, 30, 488-494.

44. Mazzini, F.; Relva, M.; Malizia, L. Impacts of domestic cattle on forest and woody ecosystems in southern South America. Plant. Ecol. 2018, 219, 913-925. [CrossRef]

45. Hernández-Valencia, I.; López-Hernández, D. Pérdida de nutrimentos por la quema de la vegetación en una sabana de Trachypogon. Rev. Biol. Trop. 2002, 50, 1013-1019.

46. Mapiye, C.; Mwale, M.; Chikumba, N.; Chimonyo, M. Fire as a rangeland management tool in the savannas of southern Africa: A review. Trop. Subtrop. Agroecosystems 2008, 8, 115-124.

47. Clark, P.E.; Williams, C.J.; Kormos, P.R.; Pierson, F.B. Postfire grazing management effects on mesic sagebrush-steppe vegetation: Mid-summer grazing. J. Arid. Environ. 2018, 151, 104-112. [CrossRef] 